Reviews

"plain brutes" (p. 50) the leaders of Africa. After independence they were "absolutely awful but their successors have been even worse" (p. 7). Nkrumah, with his "crazed dream" of socialism and unity for Africa, is their bête noire, slammed for "his vanity, ideological duplicity and disingenuousness" (p. 42). Jerry Rawlings does not fare much better: he was "a typical African despot," the "great whale" (p. 163), though apart from bumping-off his predecessors, the authors are unable to nail him for a truly convincing vice. Busia was "bumbling" (p. 43). Acheampong was "an incompetent tyrant" (p. 10) and "Ghana's chief kleptocrat" (p. 11). The disapprobation sweeps out to the other African leaders: Sekou Touré was "the destructive President of Guinea" (p. 66) and Eyadema of Togo "one of the worst blights ever to be cast on Africa" (p. 58).

The jacket blurb presumably has these excoriations in mind in commending the book as "courageous." One way or another, it has all been said before, and so many of the culprits are on the litigiously safe side of the grave. The thought-provoking contrast, however, is not with the Thompsons' approbation of the Thai leaders, but with their panegyrics for the bourgeois intellectuals with whom they ally themselves: "that great economist Partha Dasgupta" (p. 158); "the great development economist Robert West" (p. 14); "the learned Carl Rosberg" (p. 44); and a stream of others, many of whom rate the over-exercised label "brilliant."

At Independence, African leaders had a passionate respect for academics, and insisted on the qualifications they had acquired, one way or another: Doctor Nkrumah, Doctor Obote, Doctor Banda. Now, everywhere, and with justification, the mood is skeptical. "It's all academic now," we say, when one football team is being incontrovertibly thrashed by another. Publics, even in Africa, are getting thoroughly inured to the vacuities that stream from the ivory tower. As for liberal panaceas and moral harangues about leadership, they have certainly heard all that before. As Jerry Rawlings famously remarked, when he was being lectured by the Structural Adjustment pundits: "blah blah blah" (p. 46).

\title{
Teetering on the Rim: Global Restructuring, Daily Life, and the Armed Retreat of the Bolivian State. By Lesley Gill. New York: Columbia University Press (2000), 222 pp.
}

\section{Reviewed by Robert Albro, Department of Sociology and Anthropology, Wheaton College, Massachusetts.}

In her relatively compact urban ethnography of El Alto, Bolivia (a peripheral migrant city in Bolivia of at least half a million people) Lesley Gill asks a question we should all be asking: "what is wrong with the global economic order" (p. 181)? She asks this question in provocative ways, as well, encouraging us to think hard about the costs and benefits (if any) for people living in the onetime 3rd and 4th worlds. Cutting to the quick, for El Alto, at least, she detects virtually "no" benefit whatsoever for alteños, forced to come to terms with a draconian legacy of fifteen years of neoliberal structural adjustment. Therefore, her ethnographic goal is a study of "the complexity of local experience and the ways in which pain, loss, and desperation shape daily life" (p. 185) in El Alto, a marginal place of increasingly bleak prospects, forced to absorb the blows of neoliberalism as best it can, which is to say, often not very easily and with dire costs for those left to muddle through.

Given the increasing ubiquity and seeming inevitability of so-called "neoliberal democratization" in Latin America, detailed studies of what we might tactfully call its "fault lines" are surprisingly few and should be welcome. Gill's analysis and critique "from below" of the fallout of Bolivia's neoliberal regime for daily life in El Alto takes aim both at lacunae in the ethnographic attention to the aftermath of structural adjustment, and in the urban anthropology of the Andes. One reason why there has not been the sheer quantity of ethnography one should justifiably expect with regard to this, the most pressing global issue shaping turn-of-the-century Latin America, is the often bedeviling challenge of just exactly how to go about it. Given the intimate stock in trade of ethnography (that is, prolonged participant-observation by a single researcher in a "place"), it is a daunting task to confront such a scale and complexity of wholesale macro-level social transformation. Where to begin and how to describe the systemic effects of reform are not questions with singular or simple solutions. 
Reviews

In Gill's reckoning, "neoliberalism" is less an optimistic set of policies embodying the "magic of the market," and more a plenipotentiary "field of force" of ominous shape. If neoliberalism begins as mere economic doctrine, as applied it is nevertheless polyvalent (rather than synthetic). The ethnographer explores the deployment of this polyvalent field in El Alto as an encompassing and infecting set of economic, political and cultural-moral practices, as a whole, both a site of "struggle" and a form of domination shaping "social relationships of inequality" (p. 20). This recognition of neoliberalism as much more than just an economic solution, and as a set of cultural-moral practices with the potential to wreak havoc on intimate lived worlds, is a key step in any critique.

Gill pursues how the deeply corrosive effects of neoliberal reform aggravate "urban spoliation" (p. 50). This refers to the state's disregard for its own responsibilities toward peripheral urban neighborhoods. Urban spoliation amounts to an assault upon the very integrity, stability, and wellbeing of familial and other traditional and intimate social relations (of "class," "gender," and "ethnicity"), now fundamentally reordered as a result. As a contribution to what can be called cultural anthropology's corpus of the critique of "modernity," such an analysis is certainly what we would hope to see from an ethnographic approach grounded in what, for political scientists and economists, might be the almost irrelevant minutiae of daily life. And this is just the point. Such issues are far from irrelevant, but rather fundamental. That they must be our point of departure (rather than, say, the boons of foreign investment) lies at the very heart of Gill's undertaking.

Gill's solution, a damning "critique" of neoliberalism as an ongoing process of social dislocations and cultural conflicts, reflects her choices for the description of the problem. She provides the reader with a "multi-sited" series of snapshots of key sectors of life in El Alto (using the methods of such "postmodern" ethnographers as George Marcus). In conspicuous contrast to the by now long-established tradition of intensive "community studies" in Latin America (in the past used to explore similar issues, as with June Nash's landmark study of Bolivia's tin miners), Gill uses the "multi-sited" approach in diverse considerations of relocalized miners (chapter 4), plights of public educators (chapter 5), the role of the military (chapter 6), NGO's (chapters 7 and 8), and the ways family economies have had to diversify in the face of economic necessity. The abiding concern throughout is a commitment to understand "how changing forms of state rule are affecting the lives of vulnerable people in El Alto" (p. 4).

As a cohesive critique of neoliberal hegemony, the array of cases presented in this ethnography coexist only uneasily at times. At its best, Gill's multi-sited aperture convincingly takes in how non-governmental organizations (NGOs) are frequently ineffective as palliatives to poverty, in representing the poor, or as engines of grass-roots development. More often than not, she suggests, NGOs have come to work within the neoliberal context (rather than countering it) as a means for selective class mobility, to support the private sector, and to recreate clientelistic ties, all contrary to the interests of poor alteños. In short, Gill persuasively examines how the proliferation of NGOs in the Bolivia of "popular participation" amounts to an emerging front in a "neoliberal class war against the rights and interests of ordinary Bolivians" (p. 143), an insight applicable to other nations as well.

On the other hand, while Gill's discussion of the military is insightful - particularly in sketching out the ways that popular notions of masculinity are produced in collusion with dominant national institutions like the military - it is disconnected from the matter at hand, to whit, the question of how social rifts have been exacerbated or inculcated by recent neoliberal reform. Gill's discussion of the rifts between the armed forces and the poor is not really "time bound" in her argument as an aspect of structural adjustment, so much as an expression of hegemony in a paternalist state, a rather different matter with a distinct context. The case for neoliberalism as contributing to what Gill calls Bolivia's "low intensity version of militarized democracy" (p. 106) is not convincingly established in this short ethnography. It is also at such moments that thin ethnographic description and interpretation give way to polemics about the categorical impossibility of a humane capitalism, a view often treated in a matter of fact a priori sort of way.

With such a multi-sited, if occasionally scattershot, approach, one can wonder what happens to ethnographic thick description under a neoliberal regime. If Gill's work suggests anything, thick description is easily victimized in the "displacement" of ethnography both by the multi-sited technique itself and by the destabilizing effects of the structural adjustment process, the very object of Gill's analysis here. When inadequately framed or underdeveloped, such ethnographic detail becomes monochromatic as cipher for the polemic. One such instance is the discussion of kharasiri (pp. 51-54), a supernatural figure widely noted in the Andes, and which can take many forms. Gill briefly summarizes a single instance of kharasiri, and concludes, "The tales graphically depict feelings of vulnerability among those who are losing control of their lives as well as their bodies" (p. 54). The implication is that the desperate straits of state-sponsored health care under the neoliberal regime have either created or exacerbated such a loss of control among poor alteños. As implication, such imputed connections help create the ethnography's texture of critical indictment, while leaving the thick description of those connections for readers to infer. A multivocal figure if ever there was one, kharasiri has been interpreted in a variety of ways, though not here. It is thus not clear what kind of response kharasiri might be, if a response at all, by the "margin" to neoliberalism's refiguration of 
Reviews

social relations.

Gill's reading of the predicaments facing former miners - once members of a highly militant union movement and now casualties of privatization - is also telling. She emphasizes the established history of "worker solidarity" (p. 80) and mobilization against state-sponsored injustices, and contrasts this to the present decline of the Fordist system of labor regulation, which has created the miners' unemployment and undermined their heroic basis for struggle. Gill makes the good point that lessons of the past are not always applicable to the present. She explains how ex-miners, now primarily tenuously surviving in the informal economy, have had to distance themselves from the struggle of collective mining unionism, something she laments.

In a funny sort of sleight of hand, "collective" resistance in the mines is aligned with the "community" currently being dismantled by neoliberal reform. And yet, the state-sponsored miner's life of past decades was clearly not an enviable one, but instead characterized by the extremes of family hardship, isolation, and vulnerability to not infrequent government oppression. Collective action amid misery and fractured communities are both bleak choices, but Gill's framing of the history of miner activism serves as heroic past counterpoint to grim current reality, where collective mobilization against unjust capitalist practices seems, in her words, "extremely difficult" (p. 183).

And yet just this has happened in Bolivia, in spectacular fashion, and with an unexpectedly successful outcome. In a series of confrontations between an inter-class and inter-ethnic coalition movement and the Bolivian government between April of last year and April of this year, "ordinary Bolivians" won a major victory over global capitalism, forcing the Bolivian government to renege on a deal it made with the Bechtel corporation to privatize the water system of the department of Cochabamba. Since called the "Bolivian Water War," in effect participants were able to give the boot to a multinational corporation, Bechtel, while reasserting their local autonomy, and inalienable right to the precious resource, water. Not surprisingly, perhaps the key figure unifying and mobilizing the movement, Oscar Olivera, cut his teeth on the same style of "radical" worker union politics as the militant mining unions. It seems the outcome for a post-neoliberal Bolivian is not a totally grim and foregone conclusion, and nor is the story yet written.

In El Alto, the City of the Future, whatever might once have been "community" (and this includes the community of erstwhile "community studies) has become a "sick joke" (p. 27), an "extremely unstable amalgam of social relationships relative to the conflicts and contradictions that generate, sustain, and often dissolve it" (p. 35). Evoking and interrogating this unstable amalgam amidst neoliberal reform is no easy task, given the difficulties of tracing out its manifold and often alarming effects. We should thank Lesley Gill for taking it up.

\title{
Global Multiculturalism: Comparative Perspectives on Ethnicity, Race, and Nation, edited by Grant H. Cornwell and Eve Walsh Stoddard, Lanham, MD: Rowman \& Littlefield Publishers (2000), 368 pp..
}

\author{
Reviewed by Frank J. Lechner, Department of Sociology, Emory University.
}

For all the faddish talk of "multiculturalism" in the 1990s, there are few serious academic studies of the subject. Yet it offers scholars a great opportunity: here is an idea that spread across the globe and changed, at least among many elites, common ways of thinking about the diversity of nation-states. It would go too far to echo the title of one American essay on the subject by saying that "we" are all multiculturalists now, for "we" are not. But more and more of "us" are, and even those who aren't must now contend with a new global discourse. How, and to what extent, did multiculturalism become a global model for dealing with internal divisions? How did integrationvia-assimilation lose its luster? What does multiculturalism mean for different groups? How did it play out in particular contexts?

Reporting the results of an eight-year project on "Cultural Encounters" at St. Lawrence University, Cornwell and Stoddard shed some light on such questions. They initially equate multiculturalism with the mere fact of diversity in states made up of more than one culture or ethnic group. From this diversity stem certain tensions, notably between "cementing a national identity" and "recognizing . . . identities that can cross national boundaries" 